\section{Survey of Svalbard}

THE Norwegian Svalbard department (Norges Svalbard-og-Ishavs-undersökelser), as can be judged from the report of its activities 1936-44 (Skrifter, Nr. 88. Oslo : Jacob Dybwad, 1945. $6.50 \mathrm{kr}$.), was busy during the period of enemy occupation, although the last expedition to Svalbard was in 1939 and to East Greenland in 1941. The report contains full accounts of these expeditions and of the useful work done in Oslo in compiling various Svalbard maps, on the bibliography of Norwegian polar literature and the exhaustive report on Svalbard place names. "The Survey of Björnöya" (Bear Island), completed between 1922 and 1931, forms a separate publication with full details of the work and a revised edition of the contoured map of the island on a scale of 1 to 25,000. This is printed in brown, blue and black. Small reproductions of some of the earlier sketch maps of the island are also given. This monograph, together with that of $G$. Horn and A. K. Orvin on the geology and history of the island (Skrifter, Nr. 15. Oslo, 1928) with its geological map, form an exhaustive survey of the island, which is now one of the most carefully surveyed areas in polar regions.

Svalbard includes all the islands over which Norway acquired sovereignty by the treaty of 1920 . These islands lie between lat. $74^{\circ}$ and $81^{\circ} \mathrm{N}$., and long. $10^{\circ}$ and $35^{\circ} \mathrm{E}$. Included are Spitsbergen, Bjørnøya, Hopen, Kong Karls Land and Kvitøya. The Svalbard Archipelago has been visited by western Europeans since A.D. 1194, and it is generally agreed that the Svalbard mentioned in the Icelandic annals refers to these islands. In 1596 the Dutch arrived while trying to discover the NorthEast Passage, and from the start of the seventeenth century there was much Dutch and English whaling activity. From about 1720-1852, Russian trappers used to winter there and have left traces of their visits. Since then there have been not a few purely scientific expeditions to the region. A list of place names has now been issued (Skrifter om Svalbard og Ishavet, Nr. 80. Pp. 540. Oslo : Jacob Dybwad, 1942. 50 kr.). The names are arranged alphabetically, and bibliography, indexes and a map are included. The committee responsible is to be congratulated on a notable piece of work. It is written in English.

\section{Carnegie United Kingdom Trust}

THE thirty-third annual report of the Carnegie United Kingdom Trust, to which are appended the accounts for the year ending December 31, 1946, records the progress made during the first year's execution of the plans for the current quinquennium. The principal allocations for the quinquennium opening on January 1, 1946, are $£ 150,000$ for music and drama; $£ 100,000$ for village halls; $£ 150,000$ for the Bureau of Current Affairs; $£ 30,000$ for museum services ; $£ 25,000$ for Young Farmers' Clubs, and $£ 40,000$ for youth hostels. The Trust is constituting a small committee to examine the recommendation in Miss E. Younghusband's report on the training of social workers, for the establishment, in association with an appropriate universitv, of a Carnegie School of Social Work. A new grant has been promised to the National Federation of Women's Institutes in aid of the foundation of a residential centre, at Marcham Park, near Abingdon, to whick countrywomen may resort to study problems affecting rural life and for suitable courses of instruction. A grant up to $£ 750$ has been promised to enable the Central Landowners'
Association, together with other bodies concerned with the preservation of the countryside, to promote a competition designed to encourage the study of village planning.

Funds are being made immediately available for museum services for three main purposes : the supply of expert reports to museums which may wish to consider possible lines of development; the provision of grants to museums already able to carry out approved schemes of reorganisation; and the training of museum staffs. The Trust has continued to meet the whole cost of maintaining the Irish and Scottish Central Libraries for Students, and, in addition to renewing its grant in aid of the National Central Library, has made exceptional grants of $£ 400$ to Rutland and $£ 1,500$ to Argyll for the establishment of a county library service. A further grant of $£ 6,000$ has been promised to the Council for the Promotion of Field Studies for the adaptation and equipment of Flatford Mill as a pioneer field centre. Grants of $£ 2,500$ to the Highland and Islands Film Guild for the provision of a mobile film service in two of the crofting counties of Scotland, a capital grant of $£ 2,500$ for the adaptation and equipment of Bisham Abbey as a national recreation centre by the Central Council of Physical Recreation, and a grant of up to $£ 1,000$ a year for five years for an inquiry into certain aspects of juvenile delinquenev to be conducted at the Philanthropic Society's School, Redhill, are also recorded.

\section{Earthquake in the Philippines}

ON January 25, a series of some eleven earthquake shocks shook the central Philippine Islands for about four hours. The sugar-growing island of Panay, approximately 285 miles south-west of Manila, was most affected, and the islands of Negros, Cebu, Leyte and Marinduque, all densely populated, were also shaken. The six-storied campanile of the ancient Jaro cathedral collapsed and some fissures caused by the earthquake were more than 100 yards long. Altogether damage was caused to the extent of about $£ 100,000$, and at least twenty-seven deaths and many injuries were occasioned by the shock. The earthquake was recorded at observatories throughout the world as the greatest since the Japanese earthquake of December 21, 1946.

The Philippine Islands are definitely in a seismic zone, small shocks occurring there frequently. Considerable earthquakes are reported from time to time, and an extensive catalogue of these, from the Manila earthquake of 1589 to the Butuan earthquake of December 26, 1899, has been compiled by the Rev. William C. Repetti, S.J. Destructive earthquakes occurred at Batangas on December 14, 1901, and in the centre of Mindanas on August 21, 1902. Lehmann and Plett wrote an interesting paper on the Philippine earthquake of November 13, 1925.

\section{International Congress of Applied Mechanics}

THE Seventh International Congress of Applied Mechanics will be held at the Imperial College of Science and Technology, South Kensington, London, during September 5-11. The technical sessions will be organised under the following sections: (1) Elasticity and Plasticity; (2) Aerodynamics, Hydrodynamics, Meteorology; (3) Thermodynamics, Heat Transfer, etc. ; and (4) Vibrations, Lubrication and Experimental Methods. In addition, as many as ten general lectures or surveys are contemplated on subjects likely to be of interest to members. Arrange- 